\title{
Analysis of Environmental Factors with Chronic Diarrhea in Toddlers in Jambi City in 2019
}

\author{
Eko Mirsiyanto ${ }^{1}$, Rico J. Sitorus ${ }^{2}$, Misnaniarti ${ }^{3}$ \\ ${ }^{1}$ Department of Master of Occupational Health and Environmental Health, Faculty of Public \\ Health, Sriwijaya University, Palembang, Indonesia \\ ${ }^{2,3}$ Department of Public Health Sciences, Faculty of Public Health, Sriwijaya University, \\ Palembang, Indonesia \\ Email:mirsiyantoe@yahoo.com
}

\begin{abstract}
Chronic diarrhea is defecation with a frequency of 3 or more times in infants and children lasting for 14 days. The impact of diarrheal disease in general causes loss of fluid in the body (dehydration) and chronic diarrhea can cause a child to experience poor nutritional status and experience growth failure. This study uses a case-control design using a retrospective approach. The number of samples in this study was 135 respondents. Instruments for collecting data in the form of questionnaires and observations. Data were analyzed by univariate, bivariate using the Chi-Square test, and multivariate analysis with multiple logistic regression. The statistical test results obtained $p$-value on the variables of clean water supply (0.007), latrine ownership (0.001), sewerage system (0.04), confidence degree $95 \%$ Confidence Interval $(95 \% \mathrm{Cl})$ and $p$-value $<0,05$, it can be concluded that there is a significant relationship with chronic diarrheal disease in infants. The results of multiple logistic regression tests, on the variable wastewater discharge obtained $\mathrm{OR}=3.801$, meaning that sewerage is closely related to causing chronic diarrheal disease in infants.
\end{abstract}

Keywords: Environmental Factors, Chronic Diarrhea, Toddler.

\section{A. INTRODUCTION}

The Healthy Indonesia Program is set out in the main targets of the 2015-2019 RPJM, where one of the goals is disease control, several disease prevention, and control measures, namely through the development of an early warning and response system (EWARS) or an early alert system which is a strengthening of the early-awareness system extraordinary events (SKD-KLB). There are 23 types of diseases that have the potential for outbreaks that are monitored in the SKDR, diarrhea is one of them. Outbreaks often occur in areas with poor sanitation quality, inadequate clean water, and lots of malnutrition (Ditjen P2PL, 2015).

Diarrhea is a disease characterized by the excretion of feces with a consistency of soft to liquid with a frequency of excreting 3 times or more a day. Diarrhea is classified as acute and chronic diarrhea. Chronic diarrhea is not a unitary disease, but rather a syndrome whose causes and pathogenesis are multi-complex. The diagnosis of chronic diarrhea and its treatment is more complicated than acute diarrhea (Wiryani \& Wibawa, 2007). Meanwhile, diarrhea that lasts less than 14 days is classified as acute diarrhea (Zein, 2011). In Indonesia, the terms chronic diarrhea and persistent diarrhea are used differently, the term persistent diarrhea for those with an infectious etiological basis and chronic diarrhea for those with a noninfectious etiological basis (Irwan, 2017). 
The impact of diarrheal disease in general, especially in toddlers, causes loss of fluids in the body (dehydration), defecation that occurs continuously results in the disposal of nutrients that are very important for the body, to help the body recover and to defend the body against germs, including the cause of diarrhea itself (Irianto, 2009). Loss of electrolytes through feces can potentially lead to hypokalemia and metabolic acidosis. In cases that are late in getting help, so that the hypovolemic shock that occurs can no longer be resolved, Acute Tubular Necrosis of the kidney can occur which subsequently occurs multi-organ failure (Zein, 2011). Chronic diarrhea can cause a child to experience poor nutritional status and experience failure to thrive.

According to WHO (2013), diarrheal disease is the second disease that causes death in children under five years, namely pneumonia $(14 \%)$, diarrhea $(14 \%)$, other infections (9\%), malaria (8\%), and other diseases. not contagious (4\%). It is estimated that 1.7 million cases of the diarrheal disease occur each year, killing approximately 760,000 children under the age of $5(1.6 \%)$.

Diarrhea is a disease with the potential to cause outbreaks (KLB) in Indonesia, which is often accompanied by death. In 2017, the number of diarrhea sufferers was $60.4 \%$. The CFR target for diarrhea outbreaks is expected to be $<1 \%$. Thus nationally, the CFR of diarrhea outbreaks did not reach the program target in eradicating diarrhea disease (Budjianto (2017).

Chronic diarrhea occurs in children under 3 to $20 \%$ of all diarrhea episodes. The incidence of persistent diarrhea in some developing countries ranges from 7$15 \%$ each year and causes $36-54 \%$ of all diarrhea deaths. In Indonesia, the prevalence of chronic diarrhea is $0.1 \%$ with the highest incidence rate in children aged $6-11$ months (Wibowo, 2018).

Diarrhea sufferers in Jambi Province in 2018, the number of diarrhea sufferers in Jambi City was 3,975 cases, and the number of chronic diarrhea sufferers referred from the health center to the Jambi City regional public hospital in 2018 was 53 toddlers (Jambi Province Health Office, 2018).

Diarrheal disease is caused by various factors, namely infectious factors (bacteria, viruses or parasitic infections), dietary factors (allergies and food poisoning), decreased immune system factors (infants/toddlers do not get breast milk, nutritional status (malnutrition, malabsorption). and immunodeficiency), environmental and behavioral health factors (Ditjen P2PL, 2011). The occurrence of chronic diarrhea is not always caused by irritative bowel syndrome and non-specific inflammatory bowel disease (inflammatory bowel disease), but also caused by infections and parasites (Wiryani \& Wibawa, 2007). Furthermore, Firmansyah (2008) reports that $5 \%$ of acute diarrhea will continue for more than 14 days (chronic diarrhea), this is caused by such as age under one year, malnutrition, immune disorders, previous diarrhea history, and intestinal infections. specifics like parasites.

Infection with bacteria that causes diarrhea is usually spread through contaminated food/drink or direct contact with the patient's feces (oral feces), the transmission of diarrhea can occur through water (waterborne disease), food 
(foodborne disease) (Irianto, 2009). Environmental factors have a very large role in the spread or transmission of bacteria, viruses, and parasites as infectious factors that cause diarrhea. Some of the environmental factors associated with the occurrence of diarrheal disease are the provision of clean water, ownership of latrines, wastewater disposal systems, and landfills. and improper food preparation and storage. These two factors will interact together with human behavior if environmental factors are unhealthy and accumulate with unhealthy human behavior, then diarrhea transmission can easily occur (Sriwahyuni \& Soedirham, 2014).

WHO data shows that $88 \%$ of diarrhea cases are caused by consumption of unsanitary and healthy water, inadequate sanitation and hygiene and estimates that $94 \%$ of diarrhea incidents can be prevented by environmental modification including increased availability of clean water, and improved sanitation and hygiene. Good sanitation is an important element that supports human health. Sanitation is related to environmental health which affects the degree of public health. Poor sanitation conditions will have a negative impact on many aspects of life, starting from the decline in the quality of the community's living environment, the increasing number of diarrhea incidents, and the emergence of various other diseases (Prajnyaswari \& Putri, 2013).

The achievement of environmental health to prevent various infectious diseases has not shown satisfactory results. This is following the data from the results of basic health research (RISKESDAS) in 2018, namely the management of household waste that is burnt $49.5 \%, 7.8 \%$ disposed of in rivers or gutters, and $5.9 \%$ disposed of in any place and handling of under-five discard in any place amounting to $33.5 \%$. Achievement of access to clean water for clean water nationally is $71.14 \%$, and in Jambi Province, This activity has resulted in the community's access to clean water, namely $60.78 \%$ in 2015 and $62.75 \%$ in 2016. Research conducted by Adisasmito ( 2007), where research on diarrhea was carried out using the Systematic review method, showing that the most studied risk factor for diarrhea disease is environmental factors.

So far, there have been many studies on risk factors that cause diarrhea in toddlers, but there are not many studies on risk factors for chronic diarrhea in infants and toddlers. Apart from abnormalities in the intestine, chronic diarrhea is also caused by infections caused by viruses, bacteria, and parasites. Environmental factors play a vital role as a means of transmitting the disease, diarrhea in toddlers. Therefore, it is necessary to research chronic diarrhea with the title analysis of environmental factors on chronic diarrhea disease incidence in children under five in Jambi City in 2019.

\section{B. METHOD}

This study uses a case-control design using a retrospective approach, which is studying how risk factors are identified at this time, then the risk factors are 
identified as having or occurring in the past using data from interviews with questionnaires and observations (Sugiyono, 2011).

The population in this study were mothers of toddlers or people and caregivers of toddlers who suffer from diarrhea in the city of Jambi. The sample size is 45 respondents as cases. The comparison of case and control samples is 1: 2 . So that the number of samples in this study was 135 respondents.

\section{RESULT AND DISCUSSION}

\section{The Relationship between Clean Water Supply and Chronic Diarrhea in Toddlers}

The relationship between clean water supply and chronic diarrhea in children under five can be seen in the following table:

Table 1.The Relationship of Clean Water Provision and the Incidence of Diarrhea in Toddlers in Jambi City in 2019

\begin{tabular}{|c|c|c|c|c|c|c|c|c|}
\hline \multirow{3}{*}{$\begin{array}{c}\text { Clean Water } \\
\text { Supply }\end{array}$} & \multicolumn{4}{|c|}{ Diare } & \multirow{2}{*}{\multicolumn{2}{|c|}{ Total }} & \multirow{3}{*}{$p$-value } & \multirow{3}{*}{$\begin{array}{c}\text { PR } \\
(95 \% \text { CI })\end{array}$} \\
\hline & \multicolumn{2}{|c|}{ Chronic } & \multicolumn{2}{|c|}{ Acute } & & & & \\
\hline & $\mathrm{n}$ & $\%$ & $\mathrm{n}$ & $\%$ & $\mathbf{n}$ & $\%$ & & \\
\hline Not Good & 30 & 9,1 & 30 & 90,9 & 33 & 100 & \multirow{2}{*}{0,013} & 2,737 \\
\hline \multirow[t]{2}{*}{ Good } & 15 & 21,4 & 55 & 78,6 & 70 & 100 & & $(1,296-5,781)$ \\
\hline & 45 & 100 & 90 & 100 & 135 & 100 & & \\
\hline
\end{tabular}

Based on the table above, it can be seen that out of 45 respondents with children under five suffering from chronic diarrhea, there were $30(66.7 \%)$ respondents with poor clean water supply. The statistical test results obtained pvalue $=0.013$ ( $\mathrm{p}$-value $\leq \alpha(0.05))$, it can be concluded that there is a significant relationship between the provision of clean water and the incidence of chronic diarrhea in children under five. From the analysis, it was also obtained that the OR value $=2.737(1.296-5.781)$, meaning that respondents with poor clean water supply have a chance of 2.737 times that their children suffer from chronic diarrhea when compared to respondents with good clean water supply.

Based on the results of the study, it is known that children who suffer from chronic diarrhea live in the respondent, with the provision of clean water, latrines, and household sewerage that is not good enough to increase the risk of contamination with pathogenic bacteria, so that if consumed it will cause diarrhea, where infectious germs The cause of diarrhea is transmitted through the fecal-oral route, namely by entering into the mouth, fluids or objects contaminated with feces, for example, drinking water, fingers, and food in contact with water contaminated with pathogens that cause diarrhea. This opinion is supported by Widoyono (2010), who explains that the transmission of diarrhea disease to children under five is usually through water, which is the main transmission medium. Diarrhea can occur when a person uses water that is already polluted, either contaminated from the source or polluted during trips to the house and during storage.

Lack of access to adequate water and sanitation leads to exposure to pathogens through water, sewage, toxins, and water collection and storage routes, 
resulting in enormous health impacts on communities. The large burden of death and disability due to lack of access to clean water and sanitation is specifically associated with diarrhea, intestinal worms, schistosomiasis, and trachoma. Microbiological contamination of drinking water is high in the study area, and the risk from other chemical elements is low. Therefore, engineering solutions must focus more on improving the microbiological quality of drinking water (Edokpayi, 2018).

The use of polluted water will certainly have a negative impact on its use, either directly or indirectly. So that monitoring the use of drinking water, because the use of contaminated water plays a role in disrupting health, namely:

a. As a medium for spreading disease directly to humans.

b. As a medium for breeding germs (Mallongi, 2016).

To prevent water contamination, the various provisions described earlier can be used as a means or guidelines. Practically all wastewater will flow into the environment, must meet the applicable standards. If the water does not meet the standard, it is necessary to make efforts to be able to fulfill it/for this it is necessary to find the source of the pollution, as well as the impurity, so that the control method can be determined (Slamet, 2009).

Some of the efforts that can be made so that the family or community can achieve the provision of clean water sources that meet the requirements are expected for health workers to evaluate environmental sanitation programs and eradicate infectious diseases, one of which is diarrhea. Do social health marketing to the community. Involving community participation in this program, it is hoped that the realization of water supply that meets health requirements, so that the incidence of chronic diarrhea in children under five can be reduced as low as possible.

\section{Latrine Relationship with Chronic Diarrhea in Toddlers}

The results of the analysis between latrines and the incidence of acute diarrhea in children under five can be seen in the following table:

Table 2.The Relationship of Clean Water Toilets and the Incidence of Diarrhea in Toddlers in Jambi City in 2019

\begin{tabular}{|c|c|c|c|c|c|c|c|c|}
\hline \multirow{3}{*}{ Latrine } & \multicolumn{4}{|c|}{ Diare } & \multirow{2}{*}{\multicolumn{2}{|c|}{ Total }} & \multirow{3}{*}{$p$-value } & \multirow{3}{*}{$\begin{array}{c}\text { OR } \\
(95 \% \mathrm{CI})\end{array}$} \\
\hline & \multicolumn{2}{|c|}{ Chronic } & \multicolumn{2}{|c|}{ Acute } & & & & \\
\hline & $\mathbf{n}$ & $\%$ & $\mathbf{n}$ & $\%$ & $\mathbf{n}$ & $\%$ & & \\
\hline Not Good & 34 & 75,6 & 41 & 45,6 & 75 & 55,6 & \multirow{2}{*}{0,001} & 3,694 \\
\hline \multirow[t]{2}{*}{ Good } & 11 & 24,4 & 52 & 54,4 & 60 & 44,4 & & $(1,666-8,912)$ \\
\hline & 45 & 100 & 90 & 100 & 135 & 100 & & \\
\hline
\end{tabular}

Based on the table above, it can be seen that out of 45 respondents with toddlers suffering from chronic diarrhea, 34 (75.6\%) had a latrine that was not good, meanwhile. The results of statistical tests obtained $\mathrm{p}$-value $=0.002$ ( $\mathrm{p}$-value $\leq \alpha$ $(0.05))$, it can be concluded that there is a significant relationship between latrines and the incidence of chronic diarrhea in children under five. From the analysis, the 
OR $=3,694(1,666-8,912)$, which means that respondents with poor latrines have a chance of 2,737 times their toddlers to suffer from chronic diarrhea when compared to respondents with good latrines.

Having a family toilet with due observance to the requirements of good health can prevent the transmission of chronic diarrhea disease caused by the infection route. Therefore, the purpose of disposing of feces in a sanitary manner or meeting health requirements is to accommodate and isolate feces in such a way that direct or indirect contact between feces and humans can be prevented and the transmission of fecal borne diseases from sufferers to healthy people can be avoided and environmental pollution in general. Human waste, feces is the most dangerous for health. One gram of fresh feces from an infected person can contain about 106 viral pathogens, 106-108 pathogenic bacteria, 104 protozoan cysts or oocysts, and 10104 worm eggs (Mara, Lane, Scott, \& Trouba, 2010). From human feces infected with pathogenic bacteria that cause diarrhea, other chronic diarrhea bacteria, namely Escherichia coli, Campylobacter, Aeromonas, and Plesiomonas. Enteropathogenic E coli is the main cause of chronic diarrheal disease in developing countries (Bhatnagar, Gautam, Srivastava, Khan, \& Thakur, 2014)

Ownership of a family toilet that meets health requirements must be realized by the community to minimize the risk of environmental pollution caused by the condition of the latrine used by the family and prevent the spread of germs, pathogenic bacteria that cause diarrhea by insects. The improper and careless disposal of feces can contaminate water, soil, or become a source of infection and present a health hazard. The use of a latrine will be beneficial for maintaining a clean, healthy, and odorless environment. The latrine prevents the contamination of the surrounding water sources. The latrine also does not invite flies or insects that can transmit diarrhea. Through feces infected with viruses or bacteria, an animal can then land on the food or drink, so that food or drink can transmit diarrhea to people who eat it (Widayono, 2008).

Respondents who have good latrines and their children suffer from diarrhea. This may also be influenced by other factors that can cause diarrhea, such as the habit of washing hands and not washing hands with soap after defecating. This is in accordance with the theory put forward by the Directorate General of P2PL (2015) that environmental factors related to environmental sanitation and clean and healthy living habits together, these two factors will interact if these factors are not good environmental factors or unhealthy behavior. then the occurrence of diarrhea will easily occur.

Research conducted by Lindayani (2013), the statistical results of the chisquare test show that $\mathrm{p}=0.047(\mathrm{p}<\alpha)$ can be concluded that there is a significant relationship between human waste disposal facilities or latrines with the incidence of diarrhea in children under five. Poorly maintained or inadequate latrines can cause the risk of developing diarrhea, especially for toddlers, if this is supported by poor environmental sanitation, it can increase the chance that the germs that cause diarrhea are usually spread through fecal orally such as through food or drink 
contaminated with feces or contact a direct individual with diarrhea sufferer feces human waste disposal facilities have a significant effect on the incidence of diarrhea in children under five.

The results of the research by Hanif, Multani, and Kuscithawati (2011) showed that feces disposal facilities that did not meet health requirements, namely those that were not covered and easily infested by flies, were statistically not related to the incidence of acute diarrhea in children under five. The results of statistical tests carried out obtained $p$-value $=0.534$ and $\mathrm{OR}=1.14$. Poor fecal disposal in this study is not a risk factor for acute diarrhea in children under five. This is not in accordance with the prevailing theory because discharging facilities for feces that do not meet health requirements can become a spread of disease or a breeding ground for flies and can increase health risks. The results showed that both cases and controls, most of the defecation facilities (BAB) had met the requirements, and the possibility of transmitting the germs that caused diarrhea was not through defecation.

The quality of household latrines does not have a direct effect on the risk of diarrhea but was found to be important in certain circumstances, the role of parents in children in using latrines at home and household latrine sanitation can reduce the risk of diarrhea. Environmental cleanliness, measured based on an assessment of risk levels, was found to help reduce diarrhea in households. The effects of environmental hygiene are strengthened in society by increasing water coverage, suggesting that improved water and sanitation must go hand in hand to have the strongest positive effect in reducing the risk of developing diarrhea disease in children (Komarulzaman, Smits \& Jong, 2012).

Several efforts have been made to the Jambi City Health Office to review the program to eradicate infectious diseases and environmental health based on the community with a family approach. The principle of this activity is to educate the community, to be able to strive for, create a healthy environment, and foster a clean and healthy lifestyle. a habit in the community, especially in the family.

\section{Relationship of Wastewater Drainage with Chronic Diarrhea in Toddlers}

Analysis of the relationship between the sewerage system and the incidence of chronic diarrhea in children under five can be seen in the following table:

Table 3.The Relationship of Wastewater Drainage with the Incidence of Diarrhea in Toddlers in Jambi City in 2019

\begin{tabular}{|c|c|c|c|c|c|c|c|c|}
\hline \multirow{3}{*}{ Wastewater Drainage } & \multicolumn{4}{|c|}{ Diarrhea } & \multirow{2}{*}{\multicolumn{2}{|c|}{ Total }} & \multirow{3}{*}{ p-value } & \multirow{3}{*}{$\begin{array}{c}\text { PR } \\
(95 \% \mathrm{CI})\end{array}$} \\
\hline & \multicolumn{2}{|c|}{ Chronic } & \multicolumn{2}{|c|}{ Acute } & & & & \\
\hline & $\mathrm{n}$ & $\%$ & $\mathrm{n}$ & $\%$ & $\mathrm{n}$ & $\%$ & & \\
\hline \multirow{2}{*}{$\begin{array}{l}\text { Not Good } \\
\text { Good }\end{array}$} & 35 & 77,8 & 47 & 52,2 & 82 & 60,7 & \multirow[b]{2}{*}{0,007} & 3,202 \\
\hline & 10 & 22,2 & 33 & 47,8 & 53 & 39,3 & & $\begin{array}{l}(1,417- \\
7,237)\end{array}$ \\
\hline
\end{tabular}


Based on the table above, it can be seen that of the 45 respondents with under five suffering from chronic diarrhea; there were 35 (42.7\%) with a bad wastewater treatment system, while 90 respondents for children under five with acute diarrhea with a bad wastewater treatment system were as much as 47 (52.2\%). The results of statistical tests obtained $p$-value $=0.007$ ( $\mathrm{p}$-value $\leq \alpha(0.05))$, it can be concluded that there is a significant relationship between the wastewater treatment system and the incidence of chronic diarrhea in children under five. From the analysis, it was also obtained that the OR value $=3.202(1.417-7.237)$, which can be interpreted that respondents with a bad wastewater treatment system had a chance of 3.202 times their toddlers to suffer from chronic diarrhea when compared to respondents with a good wastewater treatment system.

Wastewater sourced from households is wastewater derived from wastewater from bathrooms, kitchen activities, latrines, kitchens, washing clothes, washing household appliances, and so on, which quantitatively consists of organic substances in the form of solid or liquid substances. , hazardous and toxic materials, dissolved salts, weak and bacteria, especially the faecal coli group, pathogenic bodies, and parasites. So it can be concluded that wastewater also has the risk of causing disease if it is not managed properly with a household waste water disposal system that meets health requirements.

This research shows that sewerage that does not meet the requirements greatly affects the incidence of diarrhea in children under five, this is because most residents have open sewerage channels that can cause contamination of water sources, odor, and standing water as well as wastewater these are not disposed of into the absorption ditch, but are allowed to flow away, so that they can invite the triggering of diarrhea disease vectors.

Disposal facilities for wastewater that do not meet the requirements will cause odors, disturb the aesthetics and can become a breeding ground for mosquitoes and rats, this condition can potentially transmit disease. Therefore, to prevent or reduce the contamination of wastewater to the environment which in turn has the potential to cause the occurrence of diarrheal disease, it is very important to manage the wastewater produced by households properly, so that household wastewater does not have the potential to become a breeding ground for disease germs and be a medium for disease transmission, especially chronic diarrhea in children under five. Some of these efforts provide knowledge and understanding of the importance of household waste water management for health, so that the community implements and builds SPAL properly and meets the requirements. SPAL meets the health requirements as follows:

c. Does not result in contamination of drinking water sources.

d. Does not cause surface water pollution.

e. Does not cause pollution to flora and fauna that live in water in their daily use.

f. Do not get infected by vectors or insects that cause disease.

g. It does not open and must be closed. 
h. Does not cause odor or odor.

To ensure that the community uses a good household waste water disposal system, evaluation or inspection of environmental health sanitation by health workers at the health center needs to be carried out regularly. In addition, there is also a need for information on proper waste handling in the household structure, so that the community understands and raises awareness to create an independent domestic wastewater treatment system.

\section{Analysis of Environmental Factors Most Associated with Chronic Diarrhea in Toddlers}

Based on the bivariate analysis results, all variables in this study met the requirements for further testing, namely the multivariate test. This is based on the acquisition of a p-value $<0.25$, which is a requirement for each variable to mask in the multivariate test. The multivariate test's purpose was to determine the variables most closely related to chronic diarrhea disease in children under five. For more details, see the following table:

Table 4. Multivariate Logistic Regression Analysis

\begin{tabular}{lcccccc}
\hline & & & & & \multicolumn{2}{c}{$95 \%$ C.I.for EXP(B) } \\
\cline { 5 - 8 } & B & S.E. & Sig. & Exp(B) & Lower & Upper \\
\hline Clean water supply & 1,049 &, 425 &, 014 & 2,854 & 1,242 & 6,562 \\
\hline Toilet & 1,328 &, 441 &, 003 & 3,772 & 1,590 & 8,946 \\
\hline Wastewater Disposal System & 1,335 &, 457 &, 004 & 3,801 & 1,551 & 9,317 \\
\hline
\end{tabular}

Based on the above results, the variable that most influences the incidence of chronic diarrhea is seen from the $\exp (\mathrm{B})$ value. In the variable of clean water supply and landfills, the exp value is (B). To determine which of these two variables compares the $95 \%$ C.I. for Exp (B) value and the p-value. Poor household waste disposal system is $82(60.7 \%)$, and from the multivariate test, the OR value at exp (B) $(95 \%$ CI $)$ is 11.095 and $p$-value $=0.001$.

The multivariate analysis test results show that environmental factors have a significant relationship with the incidence of chronic diarrhea in children under five. The results of this study are supported by research conducted by Paz, Almeida, and Gunther (2013), where their research identifies the relationship between diarrhea in children aged 0-2 years with access to environmental sanitation and housing conditions. The research results showed an interaction between the disposal of household wastewater that was not managed properly as a risk factor for the occurrence of diarrhea with a $\mathrm{p}$-value $=0.001$. Furthermore, from the data collected and tested with multiple logistic regressions, it can be concluded that family health programs can be an excellent tool to identify populations with poor or poor housing and sanitation conditions as risk factors for diarrhea disease.

This is in line with the research conducted by Sheth and Obrah (2004), where their research examined the effects of the intervention on the variables carried out, namely the causes of diarrhea, safe feeding practices, individual hygiene, and 
environmental sanitation. The data obtained were then compared with diarrheal diseases of children who had diarrhea in varying degrees of severity. The total reduction in the incidence of diarrhea was 52\%. Most of the households had environmental sanitation $50.5 \%$, and after the intervention, $55 \%$ of the subjects who had a bad score increased very well only increased by $14 \%$. The improvement in the environmental sanitation score was found to be statistically significant $(\mathrm{p}<0.001)$. The aspects that are considered for good environmental sanitation scoring or assessment are the absence of defecating in the pool, the presence of a closed trash can outside the house, the absence of flies inside and outside the house, and the general cleanliness of the house.

Based on the description above, intervention on environmental health to reduce the risk of diarrhea is a must that can be done considering that an unhealthy environment plays a role in the spread of chronic diarrhea infection in children under five. This is based on a development strategy in the health sector. Thus, it is hoped that the health office will review the Government's program, which launched the 5 pillars in the Environmental-Based Total Sanitation (STBM) program to reduce environmentally-based diseases such as chronic diarrhea. The five pillars are stopping open defecation, washing hands with soap, managing drinking water, household food, managing household waste, and managing household liquid waste. Involving the community to carry out these activities, such as assisting the community in improving environmental quality.

\section{CONSLUSION}

The results showed that the provision of clean water, latrine ownership, and wastewater disposal systems had a positive and significant relationship with chronic diarrhea disease in children under five in Jambi City in 2019. The variable with the most significant relationship with the occurrence of chronic diarrhea in children under five Jambi City 2019 is a variable for the wastewater disposal system.

\section{REFERENCES}

Adisasmito, W. (2007). Faktor Risiko Diare Pada Bayi dan Balita di Indonesia: Systematic Review Penelitian Akademik Bidang Kesehatan Masyarakat. Makara, 11, 1-10.

Bhatnagar, S., Gautam, R., Srivastava, G., Khan, K. A., \& Thakur , S. (2014). Chronic diarrhea in North Indian children: a Widening Etiological Spectrum. International Journal of Contemporary Pediatrics, 32-41.

Budijanto, D. (2018). Data Dan Informasi, Profil Kesehatan Indonesia 2017. Jakarta: Kementerian Kesehatan Republik Indonesia.

Ditjen P2PL. (2015). Rencana Aksi Program Pengendalian Penyakit Dan Penyehatan Lingkungan Tahun 2015-2019. Jakarta: Direktorat Jenderal Pengendalian Penyakit dan Penyehatan Lingkungan. 
Edokpayi , J. N., Rogawski , E. T., Kahler , D. M., Hill , C. L., Reynolds , C., Nyathi , E., ... Bessong , P. (2018). Challenges to Sustainable Safe Drinking Water: A Case Study of Water Quality and Use across Seasons in Rural Communities in Limpopo Province, South Africa. Water, 1-18.

Hanif, Mulyani, N. S., \& Kuscithawati, S. (2011). Risk Factors of Acute Diarrhea in Under fives. Berita Kedokteran Masyarakat, 27(1), 10-17.

Irianto, K. (2009). Epidemiologi Penyakit Menular dan Tidak Menular Panduan Klinis. Bandung: Alfabeta.

Komarulzaman, A., Smits, J., \& Jong, E. D. (2012). Clean Water, Sanitation and Diarrhoea in Indonesia: Effects of household and community factors. Netherland: Institute for Management Research, Radboud University Nijmegen.

Lindayani, S., \& Azizah, R. (2013). Correlation between Basic House Sanitation and Diarrhea on Children Under Five Years Old at Ngunut Village, Tulung Agung. Jurnal Kesehatan Lingkungan, 5.

Mallongi., A. (2016.). Current Issu. Ilmu Kesehatan Lingkungan. Yogyakarta.: Penerbit Writing Revolution.

Mara, D., Lane, J., Scott, B., \& Trouba, D. ( 2010, November). Sanitation and Health. PLoS Medicine, 1-7.

Paz, M. G., Almeida, F. M., \& Günther, W. M. (2012, Mar). Diarrhea in children and sanitation and housing conditions in periurban areas in the city of Guarulhos. Rev Bras Epidemiol, 188-197.

Prajnyaswari, D. A., \& Putri, W. C. (2013). Gambaran riwayat kejadian diare pada balita dan pelaksanaan PHBS dalam tatanan rumah tangga di Desa Gegelang Kecamatan Manggis tahun 2013. Intisari Sain Medis, 10-18.

Sheth, M., \& Obrah, M. (2004). Diarrhea Prevention Through Food Safety Education. Indian Journal of Pediatrics, 879-880.

Slamet, S. J. (2003). Kesehatan Lingkungan. Yogyakarta: Gajah Mada University Press.

Sriwahyuni, M., \& Soedirham, O. (2014). Hubungan Faktor Lingkungan Dan Perilaku Ibu Dengan Penyakit Diare Pada Balita di Surabaya. Jurnal Promkes, 2, 195-205.

Sugiono. (2011). Metode peneltian kuantitatif dan kualitatif RED. Bandung: Alfbeta.

WHO. (2013). Ending Preventable Child Deaths from Pneumonia and Diarrhoea by 2025. Switzerland: WHO Press.

Widoyono. (2011). Penyakit Tropis. Epodemiologi Penularan dan Pemberantasannya. Jakarta: Erlangga.

Wiryani, N. C., \& Wibawa, N. I. (2007). Pendekatan Diagnostik dan Terapi Diare Kronis. In J. Peny, Ilmu Penyakit Dalam (pp. 66-78). Denpasar: Unud.

Zein, U. (2011). Diare Akut Dewasa. Medan: USU Press. 